\title{
DARI POHON HAYAT SAMPAI \\ GUNUNGAN WAYANG KULIT PURWA \\ (Sebuah Fenomena Transformasi Budaya)
}

Muhajirin

Fakultas Bahasa Seni Universitas Negeri Yogyakarta

Abstrak

Pohon hayat merupakan pohon yang mampu memberikan hayat atau kehidupan bagi umat manusia yang dipercaya memberikan pengayoman dan perlindungan serta mempertebal semangat dan keyakinan masyarakat. Sisa-sisa kepercayaan terhadap pohon ayat itu sampai sekarang. Pada jaman kebudayaan Jawa Islam, kepercayaan terhadap pohon hayat tetap berkembang, bahkan bentuk gunungan wayang yang juga disebut kekayon kemudian ditafsirka berasal dari basa Arb khayyu (kehendak), dan setelah mencirkan menjadi khayu-an khayyun (kn kayon (kekayon). Perkapat akhiran an

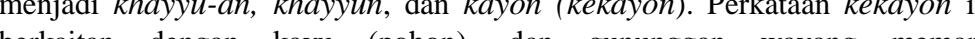
berkaitan dengan kayu (pohon), dan gunnggan wayang memang menggambarkan sebuah hutan yang lebat. Jadi bentuk gunungan (kekayon) wayang kulit purwa merupakan perkembangan lebih lanjut dari poho Kalpataru yang sudah terkenal sejak jaman kebudayaan Hindu Jawa .

Kata Kunci: Pohon Hayat, Gunungan Wayang Kulit Purwa, transformasi budaya

\section{PENDAHULUAN}

Motif gunungan telah lama dikenal oleh nenek moyang bangsa Indonesia. Dalam pergelaran Wayang Kulit Purwa di Jawa, gunungan memegang peranan penting, seperti yang dikemukakan Hoop (1950:280) sebagai berikut:

Dalam permainan bajang-bajang Djawa jaitu permainan Wajang Kulit,

ditaruh dimuka tabir (kelir) sebelum dan sesudah permainan, dan juga di antara babakan-babakan, sesuatu benda menjerupai kipas,...berasal dari Djawa Tengah. Benda ini disebut 'gunungan' (sebetulnja pegunungan) disebut djuga 'kekajon'...Gunungan ini melambangkan lagi djumlah kesatuan, keesaan, oleh karena itu sama dengan pohon hajat.

Dalam pernyataan di atas jelas bahwa nama lain dari gunungan adalah pohon hayat, yang disebut juga dengan sebutan The Tree of Life atau pohon kehidupan. Jadi motif pohon hayat merupakan unsur utama dari keseluruhan bentuk gunungan wayang kulit purwa. Disini terlihat bahwa gunungan berawal dari bentuk pohon hayat yang kemudian bertransformasi menjadi gunungan. Proses transformasi budaya dari pohon hayat hingga menjadi gunungan merupakan hal yang menarik untuk dikaji mengingat gunungan merupakan salah satu wayang kulit yang sangat pelik dan memiliki arti yang sangat penting dalam 
dunia pedalangan.

Pohon hayat merupakan unsur yang paling utama pada bentuk gunungan. Istilah 'hayat' berarti hidup atau kehidupan, jadi pohon hayat merupakan pohon yang memberikan kehidupan bagi semua makhluk hidup.Gambar-gambar pengisi 'kekayon' itu yang menjadi bagian yang paling esensial atau pokok pada gambar 'kekayon' adalah Bukit dan pohonnya, yang dinamakan Pohon Paridjata atau Pauh Djanggi (dalam kesusasteraan Persekutuan Tanah Melayu). Pohon itu dipersamakan dengan Pohon Surga, Pohon Ajaib, Pohon Hidup, Pohon Pengetahuan (budi) atau Kalpataru, atau Pohon Harapan. (Sastroamidjojo: 1964:203-204)

Dari pendapat di atas, terlihat betapa besarnya arti sebuah pohon bag sebuah kehidupan yang telah senantiasa diagungkan sejak jaman leluhur bangsa Indonesia. Arti sebuah pohon sebagai sumber ilmu pengetahuan telah lama pula diketahui.

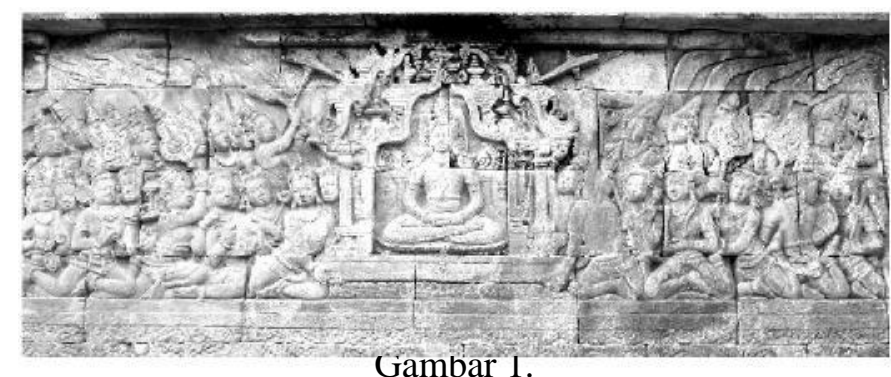

Budha Gautama saat bertapa di bawah pohon

bodhi. Sumber: Relief di candi Borobudur

Dalam ajaran agama Budha, dibawah pohon semacam itulah (pohon bodhi), sang Budha Gautama mendapatkan ilham atau wahyu perihal suatu agama yang kemudian tersebar luas di berbagai benua sebagai ajaran Budha. Pohon semacam itu juga memberikan pengayoman atau perlindungan. Pohon itu penuh dengan cabang, besar kecil, yang dihiasi dengan berbagai bunga dan buah. Di atas cabangnya dan diantara daun-daunnya sedang bergembira berbagai jenis burung yang seolah-olah sedang bersiul, dan dibawahnya terdapat binatangbinatang berpasangan.

Kegemaran melukis pohon hayat sebagai pohon kehidupan, pohon keinginan, dan pohon keramat, secara luas digarap sebagai hiasan pada kain, kulit, logam maupun dipahatkan pada relief candi. Perbedaan media ini rupanya justru memberikan andil dalam memperkaya gubahan hiasan yang membawa keragaman gaya seni tertentu. Konsep kehidupan yang selaras dengan alam beserta sistem kepercayaannya dilukiskan dengan sangat baik di dalam bentuk gunungan. Manusia, binatang, tumbuhan dan lambang roh halus ditampilkan dalam bentuk hiasan yang harmonis dan seimbang. Pohon (kayu) atau kekayon mendapat perhatian khusus dalam penggambaran bentuk gunungan. Hal ini menggambarkan bahwa pohon hayat merupakan kepercayaan yang dihayati pada jaman dahulu dan erat hubungannya dengan masalah agama dan kepercayaan .

\section{MENGENAL POHON HAYAT}

\section{Asal Mula Pohon Hayat}

Pohon Hayat disebut juga pohon kalpataru. Kalpataru berasal dari akar kata 'kalp' yang berarti 'ingin atau 'keinginan', pohon yang dapat mengabulkan segala keinginan manusia yang memujanya. Menurut Soediman, Kalpataru berasal dari kata 'kalpa' yang berarti 'masa dunia', suatu periode yang sangat lama, yaitu periode antara penciptaan dan penghancuran dunia, serta, 'taru" yang berarti "pohon'(http://kalpataru.com).

Masalah pohon kalpataru ini secara umum sudah banyak dikenal, baik melalui manuskrip Jawa Kuno yaitu Kitab Kakawin Ramayana, Kitab Negarakertagama, dan Kuncarakarna Dharmakathana, maupun dari sumber yang berupa prasasti, yaitu Prasasti Yupa di Kalimantan Timur, Prasasti Puhsarang, Kubur Panjang dan Prasasti Timang. Sumber lain yang mengetengahkan gambaran pohon kalpataru ini terdapat pula pada relief candi, misalnya di candi Prambanan, Candi Plaosan, Candi Mendut, Candi Pawon, Candi borobudur, Candi Jago dan Makam Islam Sendang Dhuwur.

Kalpataru yang biasanya digambarkan pada candi-candi sebagai hiasan ornamental, berupa pohon yang dihiasi oleh manik-manik dan permata. Berikut penggambaran kalpataru pada candi Prambanan yang terkenal dengan sebutan Motif Prambanan:

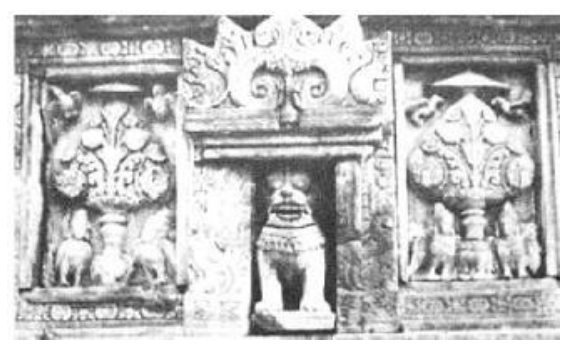

Gambar 2 . Motif Prambanan Sumber: Relief Candi Prambanan

Di bawah pohon biasanya digambarkan terdapat pundi-pundi yang mengelilingi pohon itu, di atas pohon terdapat sebuah payung dan di kiri kanan 
pohon terlihat binatang (atau makhluk) pengapit.dan di atasnya bertengge burung-burung. Kesemuanya ini merupakan satu kesatuan yang melambangkan arti simbolis tertentu. Kadang dalam pemahatannya, kalpataru dirangkaikan dengan relief cerita tertentu. Candi Prambanan merupakan satu-satunya candi Hindu yang memiliki hiasan Kalpataru.

\section{Bentuk Penggambaran Kalpataru}

Berdasarkan mitologi, pohon ini memiliki ciri antara lain daun-daunnya selalu berwarna hijau, berbunga indah dengan bau yang semerbak, berbuah penuh dengan berbagai ratna mutu manikam, mempunyai ratusan rantai emas dan untaian mutiara yang bergantungan di dahannya. Di dekat pohon juga digambarkan adanya berbagai binatang sebagai penjaga terhadap kesucian pohon itu. Kadang di sekeliling pohon juga diberi pagar atau tembok untuk memelihara kesuciannya. Di atas pohon sering pula ditaruh payung yang berfungsi untuk melindungi pohon itu dari terik matahari dan hujan.

Walaupun kalpataru digambarkan memiliki ciri-ciri seperti itu di atas, akan tetapi dalam penggambarannya dalam bentuk relief, tidak semua ciri dapat ditampakkan. biasanya hanya ciri-ciri yang bersifat konkrit saja yang dapa digambarkan, misalnya adanya pundi-pundi, pengapit, untaian manik-manik, dan permata, serta hiasan payung. Kadang-kadang, dalam penggambarannya ini ada salah satu komponen yang dihilangkan ataupun diganti dengan komponen yang lain. Kemungkinan ini terjadi karena para seniman memiliki kebebasan dalam mengembangkan kreativitasnya sepanjang tidak melanggar norma-norma yang berlaku dalam masyarakat.

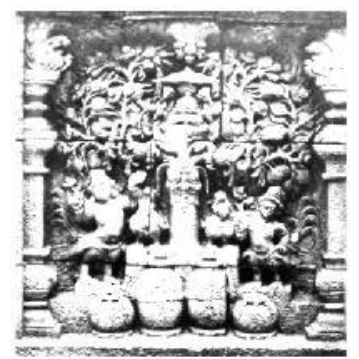

Gambar 3.

Motif Pohon hayat dengan kinara-kinari dibawahnya. Sumber: Relief Candi Prambanan

Candi merupakan replika dari gunung Meru yang dihias dengan berbagai ragam hias yang disesuaikan dengan alam lingkungan gunung itu. Hiasan-hiasan itu antara lain berupa makhluk kahyangan, seperti Gana, Apsara, Vidyadara,
Gandharwa, dan Kinara-Kinari. Untuk lebih memperkuat kedudukannya sebagai perwujudan Meru maka pada beberapa candi juga dihias dengan kalpataru yang merupakan pohon kahyangan.

Dalam sejarahnya, pemujaan terhadap pohon sudah dikenal di India sejak 3000 tahun sebelum Masehi. Pemujaan pohon ini bermula dari kepercayaan yang menganggap bahwa setiap benda yang terdapat di alam ini mempunyai kekuatan. Di atas semua itu ada sesuatu kekuatan besar yang disebut kekuatan supernatural.Kepercayaan ini muncul bersamaan dengan berkembangnya pemujaan terhadap tanah dan air.

Tanah sering diidentikkan dengan Dewi Ibu (Mother Goddess), yang dalam kebudayaan agraris dianggap sebagai dewi 'yang melahirkan' segala sesuatu di dunia ini termasuk tumbuh-tumbuhan yang dibutuhkan manusia. Tanah, dalam hal ini dianggap mempunyai hubungan religius magis dengan manusia yang bertempat tinggal di atasnya. Air merupakan unsur terpenting yang diperlukan dalam proses pertumbuhan.

Dalam sumber-sumber tertulis, Kalpataru pertama kali dijumpai dalam Prasasti Kutai. Prasasti ini menyebutkan kebaikan budi sang Mulawarman yang berwujud sedekah dalam jumlah banyak. Karena banyaknya jumlah sedekah itu maka dapat diibaratkan seperti sedekah kehidupan atau pohon kalpawrksa. Dalam cerita Tantu Panggelaran juga disebutkan tentang suatu tempat yang bernama Hiranyapura yang dipenuhi Kalpataru. Kalpataru juga ditemukan dalam karya-karya sastra Jawa kuna, seperti Udyagoparwa, Brahmandapura, Ramayana, Arjuna Wiwaha, dan Hariwijaya. (Munir: 1997:37).

\section{Mitologi Kalpataru}

Di India dikenal beberapa pohon yang dianggap suci karena adanya kepercayaan bahwa jenis pohon tertentu diyakini bisa memenuhi segala keinginan manusia. Salah satunya adalah kalpataru. Kalpataru termasuk salah satu dari lima jenis pohon suci yang terdapat di kahyangan Dewa Indra. Kelima pohon itu dikenal dengan nama Pancawreksa, terdiri atas Mandara, Parijata, Samtana, Kalpawrksa, dan Haricandana. ((Munir: 1997:38).

Sebagai pohon pengharapan, kalpataru juga disebut Kamadugha, yaitu sebagai pemberi segala hasrat dan mengabulkan segala keinginan manusia. Dengan demikian, manusia yang bernaung di bawahnya akan terkabul semua yang diharapkan. Kekayaan, wanita muda, dan segala bentuk kesenangan lainnya akan muncul pula dari pohon-pohon itu. Di samping dapat memberikan kesenangan duniawi pada manusia, pohon ini juga dapat menolong manusia dalam mencapai kebahagiaan akhir, yaitu moksa. 


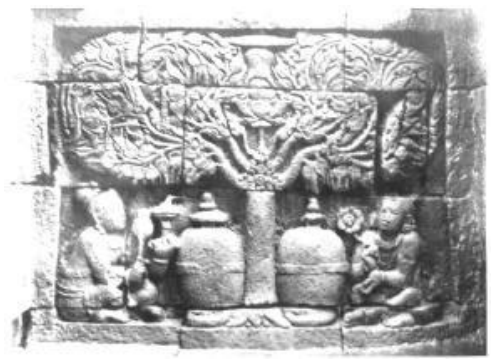

Gambar 4.

Manusia sedang bernaung di bawah Pohon Kalpataru. Sumber: Relief di candi Prambanan

Kalpawrksa merupakan padanan dari kalpataru yang secara harfiah berarti pohon yang dapat mengabulkan semua keinginan manusia yang memujanya. Pohon ini sering dipakai sebagai hiasan yang dipahatkan pada asana dewa atau singgasana raja. kalpataru juga sering dipahatkan di sini dalam Mukta prapanga (berbentuk halaman terbuka), mandapa, dan istana raja (http://kalpataru.com). Penggambarannya berupa sebuah pohon yang dililit oleh seekor ular berkepala lima dengan ekornya yang sangat panjang. Kepala ular in menjulur ke atas pohon. Banyaknya cabang serta besarnya cabang sangat bervariasi disesuaikan dengan arti penting dari singgasana itu (Munir: 1997:65)

\section{Perkembangan Sejarah Munculnya Pohon Hayat di Jawa}

Pohon hayat telah dikenal oleh masyarakat dan kebudayaan Jawa sejak jaman Prasejarah, jauh sebelum agama-agama masuk ke Pulau Jawa. Berdasarkan sumber yang diperoleh dari www.pohonhayat.com diperoleh keterangan mengenai perkembangan sejarah munculnya pohon hayat di Jawa dari era prasejarah hingga modern sebagai berikut.

Kepercayaan terhadap 'pohon hayat' yang muncul pada masa prasejarah berkaitan dengan paham animisme dan dinamisme. Pada waktu itu masyarakat percaya bahwa pada beberapa pohon tertentu terdapat kekuatan ghaib yang menjadi sumber hidup dan mampu mengabulkan segala permohonan manusia Adapun pohon yang dianggap penting pada waktu itu adalah pohon Waringin,

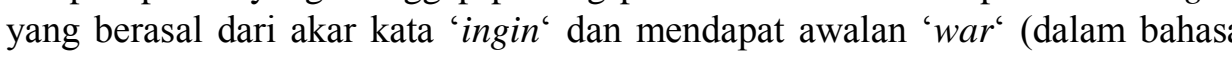
Indonesia menjadi Beringin). Selain itu juga terdapat pohon Awar-awar, Timaha, dan pohon Pelet.

Baik agama Hindu ataupun Budha yang dianut di Indonesia keduanya mengenal 'pohon hayat'. Dalam agama Buddha, pohon hayat ini dikenal dengan nama 'pohon Bodhi' yang dikaitkan dengan Pencerahan yang diterima Pangeran Sidharta. Setelah agama Buddha masuk Indonesia, nama pohon itu dikaitkan dengan pohon Waringin yang keduanya termasuk jenis Ficus religius.

Adapun dalam agama Hindu, pohon ini dikenal dengan nama kalpataru, kalpawrksa, dan memiliki arti yang dengan pohon Waringin. Menurut sumbersumber naskah Jawa Kuno sebagaimana dikutip oleh Aichele mengenai pohon kalpawrksa dalam dua bentuk. Pertama, pohon kalpawrksa yang merupakan pohon surga dan berhubungan dengan cerita mitos. Kedua, pohon kalpawrksa sebagai pohon dunia yang wujudnya dapat diamati dengan panca indra dan berupa pohon emas.

Pada zaman Jawa- Islam ini kepercayaan orang Jawa terhadap 'pohon hayat' telah mengalami perkembangan lebih lanjut. Orang Jawa menggambarkan pohon hayat ini dalam bentuk hiasan 'Gunungan' yang merupakan bentuk lain dari kalpataru. Hiasan semacam ini dapat dilihat di kompleks masjid dan makam Sunan Sendang dan juga pada pertunjukkan wayang.

Sampai sekarang sisa-sisa kepercayaan terhadap pohon hayat ini masih samar-samar, seperti yang tampak pada kepercayaan sebagian masyarakat Jawa pada 'pohon waringin kurung' yang terdapat di Alun-alun Kraton Yogyakarta, yaitu Kyai Janadaru dan Kyai Dewadaru yang konon melambangkan manunggaling kawula gusti (bersatunya hamba dan Tuhannya).

Di Pulau Karimunjawa, sampai sekarang masih ditemukan pohon keramat yang diberi nama pohon dewadaru, yang mungkin perubahan dari kata dewataru. Menurut cerita setempat, pohon ini berasal dari sepasang tongkat seorang anak yang terdampar di pulau itu. Dikisahkan bahwa suatu ketika seorang ayah tega mengusir putra kesayangannya karena anak itu berani membangkang perintahnya. Anak itu kemudian pergi meninggalkan Pulau Jawa dengan naik perahu. Berharihari perahu yang ditumpanginya dihantam badai dan gelombang, hingga akhirnya ia terdampar di Pulau Karimunjawa. Setelah berjalan lama dengan kedua tongkatnya, ia beristirahat di Desa Nyamplungan. Ketika akan duduk, ia menancapkan kedua tongkatnya di atas tanah dan tiba-tiba kedua tongkat itu berubah menjadi dua pohon besar. Pohon itu dinamakan pohon dewadaru yang artinya anugerah dewa.

Sampai sekarang mitos tentang kesaktian pohon ini masih dipercaya oleh sebagian besar penduduk Pulau Karimunjawa. Pohon ini diyakini dapat menyembuhkan penyakit perut atau sebagian penawar dari gigitan ular berbisa yang banyak berkeliaran di pulau tersebut. Bahkan pohon ini dapat dijadikan sebagai semacam ajimat untuk melindungi diri dari berbagai kejahatan manusia, di samping itu juga sebagai penolak dari gangguan roh-roh jahat.

\section{Gunungan Wayang Kulit Purwa}

Telah dijelaskan di atas bahwa gunung sebagai simbol berakar dari pemikiran tentang ketuhanan digantikan dengan lambang alam. Konsep ini 
menempatkan roh nenek moyang mempunyai urusan langsung dengan kehidupan manusia; pohon dan gunung tertutup oleh rimba raya yang penuh dengan roh halus, seperti Banaspati dan Naga. Konsep inilah yang kemudian menjadi salah satu landasan penciptaan seni rupa Indonesia. Kenyataan ini dapat dilihat bahwa sejak awal seni rupa Indonesia tidak pernah merupakan penggambaran alam sekitar in seperti yang ditangkap oleh mata sebagaimana seni rupa barat. Seniman Indonesia masa lalu tertarik akan aspek lain dari objeknya, dan dengan demikian hasil seninya berupa lambang yang kasat mata dari apa yang lebih dalam sifatnya (Soedarso Sp, 1991).

Gunungan atau Kayon, berasal dari kata kayyun yang berisi mitos sangkan paraning dumadi, yaitu asal dan akhirnya hidup. Pada dasarnya ada dua jenis kayon, yaitu Kayon Wadon (Lambang Yoni) dan Kayon Lanang (lambang Lingga). Kayon Wadon disebut blumbangan karena ada lukisan sebuah telaga pada sisi depan bagian bawah. Telaga berisikan berbagai jenis ikan dan merupakan akar dari pohon Dewandaru (atau Kalpataru) yang menjulang sampa ke ujung atas kayon. Jenis Gunungan ini agak gemuk dan mempunyai lukisan simetris di kanan kirinya. Kayon lanang disebut Gapuran karena ada lukisan pintu gerbang pada sisi depan bagian bawah. Di kanan-kiri gapura dijaga oleh dua raksasa kembar, melambangkan hawa nafsu manusia ketika akan masuk ke dunia maya. Di atas gapura terdapat terdapat pohon dewandaru yang dipenuhi dengan berbagai jenis monyet dan burung melambangkan arogansi manusia. Di ranting pohon ada seekor harimau yang berhadapan dengan seekor banteng, melambangkan ancaman nafsu yang selalu mengintip manusia . Jenis gunungan ini agak runcing dan lukisannya tidak simetris. Pada sisi belakang kedua jenis kayon ini dilukiskan kobaran api berwarna merah dan kemamang (wajah raksasa menghadap ke muka), yang sedang menjulurkan lidahnya. Lukisan dapat pula berwarna biru (juga dengan kemamang) untuk menggambarkan luapan air atau hembusan angin. ( Haryanto, 1988).

Disebut gunungan karena bentuknya seperti gunung yang berisi mitos sangkan paraning dumadi, yaitu asal mulanya kehidupan ini dan disebut juga kayon. Gunungan bagian muka menyajikan lukisan bumi, gapura dengan dua raksasa, halilintar, hawa atau udara, dan yang asli ada gambar pria dan wanita Tempat kunci atau umpak gapura bergambarkan bunga teratai, sedang diatas gapura digambarkan pepohonan yang banyak cabangnya dengan dedaunan dan buah-buahan. Di kanan-kiri pepohonan terlihat gambar harimau, banteng, kera, burung merak, dan burung lainnya. Di tengah-tengah pepohonan terdapat gambar makara atau banaspati (wajah raksasa dari depan). Di balik gunungan terlihat sunggingan yang menggambarkan api sedang menyala. Ini merupakan sengkalan yang berbunyi geni dadi sucining jagad yang mempunyai arti 3441 dibalik menjadi 1443 tahun Saka. Gunungan tersebut diciptakan oleh Sunan Kalijaga pada tahun 1443 Saka. (Haryanto, 1988).

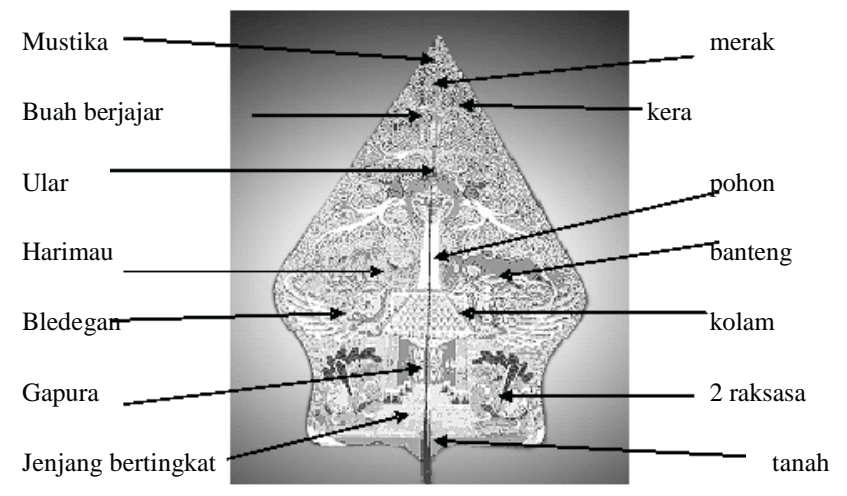

Gambar 5. Motif dalam Gunungan

Sumber: http://jv.wikipedia.org/wiki/Wayang Purwa

Gunungan secara lengkap biasanya terdapat lukisan terdiri diri:

a) Rumah Atau Balai Yang Indah Dengan Lantai Bertingkat Tiga Dan Pada Bagian Daun Pintu Rumah Dihiasi Lukisan Kamajaya Berhadapan Dengan Dewi Ratih.

b) Dua Raksasa Berhadapan Dengan Membawa Senjata Pedang Atau Gada Lengkap Dengan Tamengnya.

c) Dua Naga Bersayap.

d) Hutan Belantara Penuh Dengan Satwanya.

e) Gambar Harimau Berhadapan Dengan Banteng.

f) Pohon Besar Ditengah Hutan Yang Dililit Seokar Ular.

g) Kepala Makara Di Tengah Pohon.

h) Dua Ekor Kera Dan Lutung Sedang Bermain Diatas Ranting.

i) Dua Ekor Ayam Alas Sedang Bertengger Diatas Cabang Pohon.

Gambar-gambar yang terdapat pada kayon tersebut menggambarkan alam semesta lengkap dengan isinya. (Ciptowardoyo, 1985). Makna kayon adalah hidup yang melalui mati, atau hidup di alam fana. Kayon dapat disamakan dengan pohon kalpataru atau pohon pengharapan, dapat pula disebut bukit atau gunung yang melambangkan sumber hidup dan penghidupan. Mikrokosmos harus seimbang. Gunungan berhenti berputar berarti dunia diam, wayang kemudia dihidangkan, makhluk mulai hidup.

Ciptowardoyo (1985) menyatakan bahwa dalam kosmologi Hindu, secara makrokosos gunungan diputar-putar di atas pentas wayang kulit untuk 
melambangkan proses pencampuran benda-benda menjadi satu, terwujudlah kemudian alam beserta isinya. Hal ini disebut 'Panca Maha Bhuta' yang melambangkan lima unsur manusia: banu (sinar-udara-sethan), bani (Brahma-api), banyu (air), Bayu (angin), dan Bantala (bumi-tanah). Dari kelima zat tersebut bercampur menjadi satu dan terwujudlah badan kasar manusia yang terdiri dari Bani, Banyu, Bayu, dan Bantala, sedang Banu merupakan zat makanan utamanya.

\section{Makna dan Simbol Gunungan}

Menurut Stutterheim dalam Sastroamidjojo (1964:217) gunungan atau kekayon adalah lambang gunung Mahameru, yakni kahyangan tempat tinggal para dewa dan merupakan pusat kehidupan.

Secara visual dijelaskan bahwa kekayon atau gunungan merupakan pusat pakeliran, bentuk segitiga sama sisi, stilirisasi dari bentuk Gunung mahameru, isi utamanya adalah bentuk pohon dan bukit. Dilacak dari namanya, gunungangunungan juga berarti gegunung atau tetunggul yang berarti paling utama atau paling kuat.

Seperti telah disebutkan di atas bahwa gunungan merupakan simbol kehidupan, jadi setiap gambar yang berada di dalamnya melambangkan seluruh alam raya beserta isinya mulai dari manusia sampai dengan hewan serta hutan dan perlengkapannya.

Berdasarkan sumber dari " $\underline{h t t p: / / j v . w i k i p e d i a . o r g / w i k i / W a y a n g ~ P u r w a ~}$ mengenai makna dan simbol gunungan, dijelaskan bahwa gunungan dilihat dar segi bentuk segi lima, mempunyai makna bahwa segi lima itu lima waktu yang harus dilakukan oleh agama adapun bentuk gunungan meruncing ke atas itu melambangkan bahwa manusia hidup ini menuju yang di atas yaitu Allah SWT.

Gambar pohon dalam gunungan melambangkan kehidupan manusia di dunia ini, bahwa Tuhan telah memberikan pengayoman dan perlindungan kepada umatnya yang hidup di dunia ini. Beberapa jenis hewan yang berada didalamnya melambangkan sifat, tingkah laku dan watak yang dimiliki oleh setiap orang. Gambar kepala raksasa itu melambangkan manusia dalam kehidupan sehari mempunyai sifat yang rakus, jahat seperti setan. Gambar ilu-ilu Banaspati melambangkan bahwa hidup di dunia ini banyak godaan, cobaan, tantangan dan mara bahaya yang setiap saat akan mengancam keselamatan manusia. Gambar

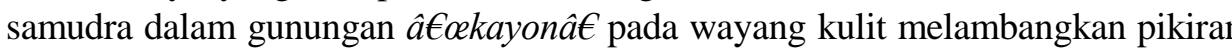
manusia. Gambar Cingkoro Bolo-bolo Upoto memegang tameng dan gada dapa diinterprestasikan bahwa gambar tersebut melambangkan penjaga alam gelap dan terang. Gambar rumah joglo melambangkan suatu rumah atau negara yang di dalamnya ada kehidupan yang aman, tenteram dan bahagia. Gambar raksasa digunakan sebagai lambang kawah condrodimuka, adapun bila dihubungkan dengan kehidupan manusia di dunia sebagai lambang atau pesan terhadap kaum yang berbuat dosa akan di masukkan ke dalam neraka yang penuh siksaan. Gambar api merupakan simbol kebutuhan manusia yang mendasar karena dalam kehidupan sehari-hari akan membutuhkannya.

Sementara itu menurut Sastroamidjojo (1964: 203-226) dijelaskan mengenai makna simbolik dari motif gunungan sebagai berikut.

a) Tanah, disebut juga lemahan, merupakan lambang empat unsur manusia, yakni: bumi, geni, banyu, angin. Manusia yang diciptakan Tuhan pertama kali yakni Nabi Adam, dibuat dari tanah. Keempat unsur ini merupakan satu kesatuan yang membuat manusia dapat hidup.

b) Pintu gerbang dengan jenjang bertingkat, melambangkan pintu masuk dari alam fana ke alam baka, terpisahnya roh dan raga. Sedangkan jenjang bertingkat melambangkan jalan penuntun agar manusia mentaati tuntunan agama.

c) Dua raksasa penjaga pintu gerbang, disebut Kala dan Anukala, merupakan simbol dari malaikat Munkar dan Nakir yang menanyai mayat dalam kubur, jika dijawab dengan benar maka malaikat akan mengucapkan selamat, apabila tidak maka akan disiksa dan dihina.

d) Air di kolam, merupakan tirta amerta, air kehidupan, yang didalamnya kisah mahabarata merupakan minuman khusus paradewa. Air juga melambangkan darah yang membuat manusia hidup.

e) Bledhegan, berjumlah 2 buah, melambangkan nafas manusia, juga melambangkan keperkasaan.

f) Pohon dan permata, disebut pohon nagasari/kalpawreksa/parijatha atau pohon surga. Didalam Wedha disebut Pauh Janggi, memberi ketidakmatian, sebagai sumber kehidupan bagi semua makhluk. Dipuncaknya terdapat permata sebagai mustika, mengandung makna bahwa kehidupan manusia hendaknya lurus dengan tujuan mendekatkan diri pada Tuhan.

g) Harimau dan banteng. Harimau melambangkan sifat kebuasan manusia, dengan menguasai segalanya untuk menindas yang lain. Banteng malambangkan kekuatan manusia yang kadang muncul sebagai kesombongan, cepat marah dan membabi buta tidak memperhitungkan untung ruginya. Hal ini merupakan godaan, apabila manusia dapat mengatasinya maka ia akan mendapatkan mutiara kehidupan dan surga.

h) Ular, melambangkan budi manusia yang mulia, tahan lapar, gemar bertapa, sabar ketika menemui kesulitan, cerdik, cekatan dan tidak suka mendahului dengan perbuatan yang tidak terpuji, akan tetapi jika diganggu maka ia akan segera membalasnya.

i) Burung merak dan kera, burung suka berkicau melambangkan hiburan atau kenikmatan duniawi. Jika manusia terlena dibuatnya maka ia akan melupakan ibadahnya. Kera melambangkan kejahilan, karena manusia sering nyuk- 
nyukan, kurang susila. Hal ini juga merupakan peringatan kepada manusia agar mencari bekal hidup untuk persiapan menuju kehidupan akhirat, jangan jahil seperti kera. Sastroamidjojo (1964: 203-226).

Fungsi Gunungan Wayang Kulit Purwa

Dalam setiap pergelaran wayang baik wayang golek maupun wayang kulit selalu diawali dan diakhiri dengan munculnya gunungan. Fungsi dari gunungan menurut Ciptowardojo (1985:30) ada 3 yakni: 1) Dipergunakan dalam pembukaan dan penutupan, seperti halnya layar yang dibuka dan ditutup pada pentas sandiwara, 2) Sebagai tanda untuk pergantian jejeran (adegan/babak) dan 3) digunakan untuk menggambarkan pohon, angin, samudera, gunung, guruh, halilintar, membantu menciptakan efek tertentu seperti menghilang atau berubah bentuk. (Sastroamidjojo, 1964: 30)

Gunungan yang juga disebut kayon disini melambangkan semua kehidupan yang terdapat di dalam jagad raya yang mengalami tiga tingkatan, yakni:

a) Tanam tuwuh (pepohonan) yang terdapat di dalam gunungan, yang orang mengartikannya sebagai pohon Hayat atau pohon Kalpataru, yang mempunyai makna pohon hidup.

b) Lukisan hewan yang terdapat di dalam gunungan ini menggambarkan hewan-hewan yang terdapat di tanah Jawa.

c) Kehidupan manusia yang dulu digambarkan pada kaca pintu gapura pada kayon, sekarang hanya dalam prolog dalang saja.

Makara yang terdapat dalam pohon Kalpataru dalam gunungan tersebut berarti Brahma mula, yang bermakna bahwa benih hidup dari Brahma. Lukisan bunga teratai yang terdapat pada umpak (pondasi tiang) gapura, mempunyai arti wadah (tempat) kehidupan dari Sang Hyang Wisnu, yakni tempat pertumbuhan hidup. (Sastroamidjojo, 1964: 30).

Gunungan atau kayon merupakan lambang alam bagi wayang kulit purwa, menurut kepercayaan Hindu, secara makrokosmos gunungan yang sedang diputarputar oleh sang dalang, menggambarkan proses bercampurnya benda-benda untuk menjadi satu dan terwujudlah alam beserta isinya. Benda-benda tersebut dinamakan Panca Maha Bhuta, lima zat yakni: Banu (sinar-udara-sethan), Bani (Brahma-api), Banyu (air), Bayu (angin), dan Bantala (bumi-tanah). Dari kelima zat tersebut bercampur menjadi satu dan terwujudlah badan kasar manusia yang terdiri dari Bani, Banyu, Bayu, dan Bantala, sedang Banu merupakan zat makanan utamanya.

Makna kayon adalah hidup yang melalui mati, atau hidup di alam fana Kayon dapat pula diartikan pohon hidup/pohon hayat atau pohon budhi tempat Sang Budha bertapa. Kayon dapat disamakan dengan pohon kalpataru atau pohon pengharapan. Dapat pula disebut bukit atau gunung yang melambangkan sumber hidup dan penghidupan

\section{Transformasi Bentuk Pohon Hayat Menjadi Gunungan}

Gunungan disebut juga Kayon atau kekayon, yang berasal dari kata kayu, yang berasal dari pohon. Jadi asal muasal gunungan adalah dari pohon, yaitu pohon hayat atau pohon kehidupan. Dalam Konsep Hindu, pohon hayat disebut juga pohon Kalpataru, yaitu sebuah pohon yang dapat memberikan apa saja yang diminta. Pohon hayat juga juga dianggap sebagai pohon yang hanya ada satu di dunia akhirat sehingga banyak digambarkan pada candi-candi.

Bentuk pohon hayat juga ditemukan pada sebuah ukiran kayu dari Cirebon Jawa Barat, dimana terdapat pembagian yang serba mendua yaitu dunia atas dan dunia bawah. Dunia atas digambarkan burung dan dunia bawah digambarkan dengan ular, dan keesaan Tuhan digambarkan dengan pohon hayat yang keluar dari bunga teratai yang tumbuh di gunung (Hoop, 1950:278).

Pohon Hayat yang telah lama dikenal oleh nenek moyang kita ini juga terdapat di candi Prambanan, yaitu pada 'Motif Prambanan'. Disebut demikian karena ciri khasnya, motif tersebut tidak ada di tempat lain. Motif Prambanan terletak di bagian luar pagar langkan/balustrade/kutamara pada candi Shiwa, Brahma, Wishnu, Nandi, Candi Garuda dan Candi Angsa. Secara visual Motif Prambanan terdiri atas tiga bidang, bidang tengah terdapat relung berisi singa jantan duduk (raja hutan, lambang kekuatan), posisi frontal. Di atas singa terdapat antevik (stiliran gunung Himalaya, Kahyangan, tempat para Dewa) berpuncak lima. Antevik ini dirangkai dengan dua makara menjulur ke bawah mengapit singa. Di sebelah kanan dan kiri bidang tengah terdapat sepasang kalpataru/pohon hayat.

Motif Prambanan berbentuk simetris, merupakan suatu keseimbangan yang sangat indah pada periode seni rupa klasik di Indonesia. Secara historis motif tersebut diciptakan oleh Dinasti Sanjaya dari kerajaan Mataram Hindu yang berada di Jawa Tengah sekitar abad ke- 7 hingga ke -9 Masehi. Berdasarkan Prasasti Siwagrha yang berangka tahun 856 Masehi yang dikeluarkan oleh Rakai Pikatan menyatakan bahwa hari Kamis Wage tanggal 11 Bulan Margacirsa tahun Caka 778 (11 November 856 Masehi) candi Prambanan selesai dibangun dan diresmikan. (Murtjipto, 1982:68).

Motif Prambanan dipahat dalam bentuk relief tinggi, merupakan perpaduan dari motif flora, fauna dan geometris yang sangat serasi dan menyatu dengan indahnya. Bahan pembuatannya terbuat dari batu andhesit (batu hitam dari Gunung Merapi). Sepasang Kalpataru/Pohon Hayat digambarkan tumbuh dari guci yang dikelilingi empat buah pundi-pundi yang dihiasi untaian permata. Untaian permata ini terjulur dari rimbunan daun dan sepasang bunga teratai yang sedang mekar. 


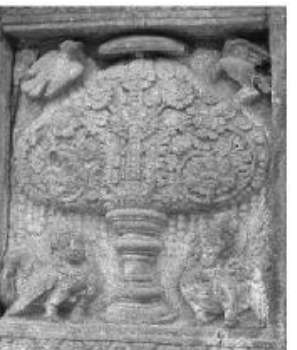

Gambar 6. Motif Prambanan

Sumber: Relief candi Prambanan

Motif Prambanan dipahat dalam bentuk relief tinggi, merupakan perpaduan dari motif flora, fauna dan geometris yang sangat serasi dan menyatu dengan indahnya. Bahan pembuatannya terbuat dari batu andhesit (batu hitam dari Gunung Merapi). Sepasang Kalpataru/Pohon Hayat digambarkan tumbuh dari guci yang dikelilingi empat buah pundi-pundi yang dihiasi untaian permata. Untaian permata ini terjulur dari rimbunan daun dan sepasang bunga teratai yang sedang mekar. Bentuk bunga dan dedaunan tersebut secara global berbentuk segi tiga, serupa dengan gunungan. Di atas pohon terdapat payung yang disebut Cattra, melambangkan perlindungan, di kanan dan kiri cattra terdapat sepasang burung terbang yang cukup dinamis. Sedangkan pohon kalpataru tersebut diapit oleh kinara kinari, sepasang makhluk kahyangan yang berujud ganjil, yaitu berbentuk kepala manusia bermahkota dengan penggambaran kepala manusia sampai ke dada, menyatu dengan bentuk burung. Makhluk ini berfungsi sebagai penjaga Kalpataru, yaitu Pohon Kahyangan, disebut juga Pohon Hayat. Pada hakekatnya bentuk ini merupakan cikal bakal bentuk gunungan yang berkembang dewasa ini (Murtjipto: 1982:69)

Gunungan dalam pergelaran Wayang Kulit Purwa di Jawa Tengah, terdapat, disebut juga kekayon, diletakkan di depan kelir sebelum dan sesudah pertunjukan wayang. Gunungan melambangkan jumlah kesatuan, keesaan dan oleh karena itu berarti sama dengan Pohon Hayat. Di dalamnya digambarkan berbagai motif, namun yang paling utama adalah pohon yang berdiri di tengahtengah dan bukitnya.

Dari nama gunungan ini dapat pula diartikan sebagai gegunungan atau tetunggul (Jawa), yang berarti paling utama atau paling kuat, berarti pula sebagai pikukuhing jagad. Di dalam Al Qur'an surat An Nabaa' ayat 7 disebutkan pula bahwa: '...dan gunung- gunung sebagai pasak", untuk memperkokoh benua atau pulau-pulau di bumi supaya lebih kuat, tidak mudah digeser posisinya. Hal in sejalan pula dengan mitos tentang Gunung Mahameru di India yang diangkut ke
Pulau Jawa untuk menenangkan Pulau Jawa yang selalu oleng agar menjadi kokoh.

Terkait dengan fungsinya tersebut, dijelaskan oleh Stutterheim dalam Sastroamidjoyo (1964:217) sebagai berikut:

Kekajon adalah suatu lambang gunung Meru atau Mahameru yang memang ada di India . Bentuknja adalah sesuai dengan bentuk bukit jang wajar tadi. Konturja mendekati yang asli pula. Sebagaimana diketahui bahwa bukit meru itu bagi bangsa India pada umumnja merupakan satusatunja lambang tempat kediaman Ciwa. Dalam hal ini Ciwa mendjelma menjadi Burung Garuda atau Burung Radjawali, atau burung Merak Emas. Selain itu Ciwa djuga berbagai dewa lainnja bersemajam di bukit itu. Berhubungan dengan hal-hal tersebut di atas bukit ersebut dinjatakan pula sebagai sumber hidup atau sumber penghidupan.

Sesuai dengan pengertian di atas maka kekayon atau gunungan jelas berakar dari budaya Hindu di India yang pengaruhnya sangat besar di Indonesia. Setelah agama Islam masuk ke Indonesia, unsur-unsur Hindu masih tetap hidup berkat jasa Wali Sanga di Jawa Tengah yang dengan penuh arif dan bijaksana memanfaatkan wayang kulit sebagai media dahwah.

Istilah gunungan dalam budaya Jawa sering dihubungkan dengan tiruan struktur gunung atau gambar yang menyerupai bentuk gunung. Selain itu juga dimaksudkan untuk menamai suatu rangkaian makanan sesaji yang mengunung pada upacara Gerebeg. Pengertian gunung ini oleh masyarakat Jawa telah dikenal secara luas, meskipun dalam istilah yang berbeda-beda. Gunungan secara fisik adalah bentuk makro dari sesajian nasi tumpeng yang dibuat dalam bentuk kerucut (Sularto, 1993:64). Gunungan disebut juga kekayon yang bentuknya seperti daun yang dihiasi dengan gambaran pohon besar yang dihuni oleh burung-burung dan binatang-binatang lainnya, gambaran kolam, dan gapura, semuanya terletak di atas pegunungan. Demikian pula gunungan ini haruslah dipandang sebagai gambaran 'gunung dari segala gunung' atau Meru dari sudut kebudayaan yang kehinduan (Soedarso Sp, 1991:16).

Istilah tumpeng, meru, mahameru, kekayon, pohon hayat, kalpataru, pohon kahyangan dan gunungan mempunyai satu pengertian yang berkait. Di balik semua istilah itu hanya ada satu konsep dasar tentang gunungan, yaitu gunung sebagai tempat bersemayamnya roh nenek moyang atau tempat tinggal para dewa. (Gustami SP, 1989), sebagaimana tergambar pada diagram di bawah ini: 

Tempat tinggal roh-roh
nenek moyang atau dewa

gunung

Mahameru Pohon

Meru Pohon Haya

Tumpeng I II Kalpataru /Parijatha

GUNUNGAN

Gambar 7. Diagam jalur pemikiran

$$
\text { Sumber: Gustami SP ( 1989) }
$$

Terkait dengan itu pula dalam Kitab Tantu Panggelaran juga diceritakan bahwa Gunung Mahameru di India bagian puncaknya dipindahkan ke Pulau Jawa agar tidak terus bergerak. Dalam perjalanannya ke timur gunung itu berjatuhan menjadi gunung Katog (Lawu), Wilis, Kampud (Kelud), Kawi, Arjuna, Kemukus dan puncaknya menjadi gunung Semeru. Demikian pula bangunan Meru di Bali juga mengggunakan atap tumpeng yang juga melambangkan gunung Mahameru sebagai tempat tinggal para dewa. Maka sudah sewajarnya tempat tinggal para dewa tersebut penuh dengan tumbuh-tumbuhan, seperti pohon hayat (Tree of Life), Pohon Kahyangan (Hemelboom), dan Pohon Kalpataru

Menurut pandangan lain Tuhan dianggap terwujud dalam manusia, terutama dalam Raja (Dewaraja). Daya gaib dianggap bersemayam dalam benda alam seperti gunung, batu dan api (dinamisme) atau dalam benda yang dibuat tangan manusia seperti patung dan jimat (fitisisme). Dari dasar paham itu kemudian lahirlah seni mereka, dimana roh nenek moyang yang dipuja digambarkan pada dinding gua atau di pintu rumah sebagai binatang kadal, biawak atau cicak. Demikian juga kerbau, gajah dan kuda seringkali dilukisan sebagai lambang kendaraan roh nenek moyang di alam atas. Selain itu binatang ular yang melata adalah lambang dunia bawah, sedangkan burung sebagai penggambaran roh nenek moyang sedang terbang ke surga juga melambangkan dunia atas. Dalam hubungan dengan kedua dunia ini yaitu dunia atas dan dunia bawah menurut Sudarso Sp (1991:16), pohon hayat atau pohon kehidupan adalah pohon keramat yang mampu menghubungkan kedua dunia itu sekaligus juga pohon keinginan yang dapat memberikan apa saja yang diinginkan manusia.

\section{Perkembangan Bentuk Gunungan}

Sastroamidjojo (1964:203) menjelaskan bahwa gunungan atau kayon ini dapat dibedakan menjadi dua macam yang merupakan pengembangan dari bentuk sebelumnya. Bentuk gunungan pada awalnya belum terdapat bentuk gapura atau rumah beratap, jadi masih berupa gambar kolam seperti gambar di bawah ini, oleh karenanya disebut kayon Blumbangan. Bentuk kayon seperti ini dianggap sebagai bentuk gunungan awal, yang merupakan titik tolak dari bentuk gunungan yang kini digunakan. Kayon blumbangan, bentuknya agak gemuk dan lebih pendek bila dibanding dengan kayon gapuran. Pada bagian bawah terdapat lukisan kolam dengan air yang jernih yang ditengahnya terdapat lukisan sepasang ikan berhadapan. Sedangkan pada bagian belakang bergambar lautan atau langit yang berwarna biru gradasi. (Sastroamidjojo, 1964:203).

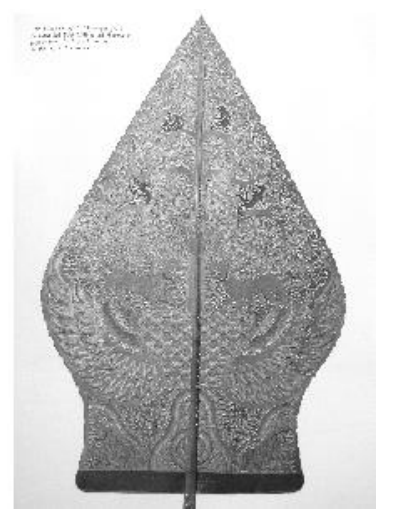

Gambar 8. Kayon Blumbangan Sumber: Sudarso Sp, 2007.

Pada perkembangan selanjutnya, bentuk kolam dengan air yang bergelombang yang masih belum jelas tersebut berubah menjadi bentuk yang lebih jelas berupa bentuk perspektif kolam beserta airnya seperti gambar di bawah ini: 


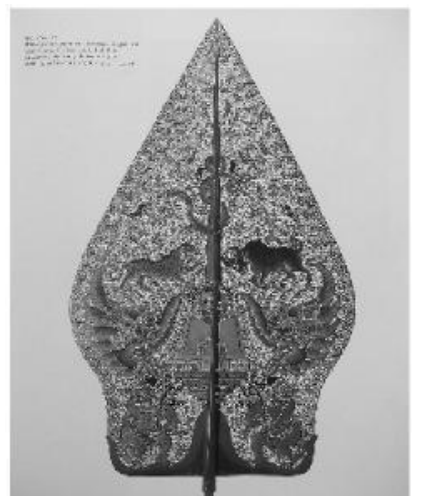

Gambar 9. Kayon Blumbangan bentuk selanjutnya.

Sumber: Sudarso Sp, 2007.

Pada perkembangan terakhir, bentuk perspektif kolam tersebut berubah menjadi bentuk atap rumah atau gapura, oleh karena itu disebut Kayon Gapuran. Kayon gapuran berbentuk ramping dan pada bagian bawah bergambar gapura yang pada sisi sebelah kiri maupun kanan di jaga oleh raksasa Cingkarabala dan Balaupata. Sedangkan pada bagian belakang terdapat lukisan api merah membara.

Bentuk gunungan wayang kulit purwa Gapuran seperti gambar di bawah merupakan kayon yang kini lazim digunakan dalam pergelaran wayang kulit purwa di Jawa. Bentuk gunungan wayang kulit purwa Gapuran seperti gambar di atas merupakan kayon yang kini lazim digunakan dalam pergelaran wayang kulit purwa di Jawa.

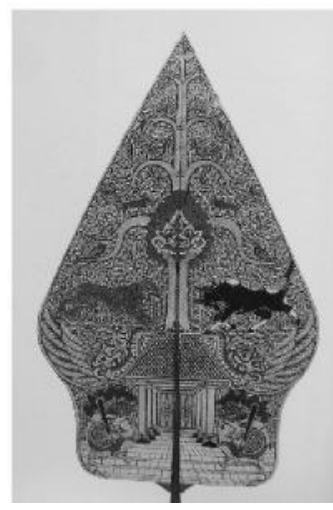

Gambar 10. Gunungan / Kayon Gapuran Sumber: Sudarso Sp, 2007
Perbedaan ketiganya terletak pada bentuk kolam dan rumahnya, sementara kesamaannya, bentuk motif pohon hayat tetap mendominasi keseluruhan bentuk gunungan tersebut karena pada dasarnya gunungan atau kayon tersebut adalah transformasi dari pohon hayat.

\section{SIMPULAN}

Arti pohon hayat kiranya sudah cukup jelas, yaitu pohon yang dipercaya mampu memberikan hayat atau kehidupan bagi umat manusia. Fungsi pohon hayat memberikan pengayoman dan perlindungan serta mempertebal semangat dan keyakinan masyarakat. Sisa-sisa kepercayaan terhadap pohon ayat itu sampai sekarang masih ada meskipun secara samar-samar.

Pada jaman kebudayaan Jawa Islam, kepercayaan terhadap pohon hayat tetap berkembang, bahkan bentuk gunungan wayang yang juga disebut kekayon kemudian ditafsirkan berasal dari bahasa Arab khayyu (kehendak), dan setelah mendapat akhiran an menjadi khayyu-an, khayyun, dan kayon (kekayon).

Perkataan kekayon ini berkaitan dengan kayu (pohon), dan gununggan wayang memang menggambarkan sebuah hutan yang lebat. Jadi bentuk gunungan (kekayon) sebetulnya hanya merupakan perkembangan lebih lanjut dari pohon Kalpataru yang sudah terkenal sejak jaman kebudayaan Hindu Jawa .

\section{DAFTAR PUSTAKA}

A. Seno Sastraomidjojo. 1964. Renungan tentang Pertunjukan Wayang Kulit. Jakarta: Penerbit PT. Kinta Jakarta,

Ciptowardoyo. 1985. Wayang sebagai Media Pendidikan Ditinjau dari Makna dan Filosofinya. Yogyakarta:Kanisius.

Hoop, van Der. 1975. Ragam-ragam Perhiasan Indonesia. Jakarta: Pemda DKI. Koentjaraningrat. 1967. Metode Antropologi. Jakarta: Penerbitan Universitas, Munir, Misbachul. 1997. "Hiasan Kalpataru pada Candi Budha Periode Jawa Tengah (Tinjauan terhadap Bentuk, Pola Penempatan, dan Fungsi”). Skripsi Sarjana Fakultas Sastra Universitas Gadjah Mada Yogyakarta. Mulder, Niels. 1973. Kepribadian Jawa dan Pembangunan Nasional, Yogyakarta: UGM Press.

Moertjipto dan Prasetyo.1992. Candi Prambanan. Yogyakarta: Kanisius.

Sudarso Sp. 1990-1991. "Seni Rupa Indonesia dalam Masa Prasejarah", dalam Mochtar Kusuma Atmadja et al (Ed). Perjalanan Seni Rupa Indonesia : Dari Jaman Prasejarah Hingga Masa Kini, Panitia KIAS.

S Haryanto. 1988. Pratiwimba Adhiluhung Sejarah dan Perkembangan Wayang, Djambatan, Jakarta.

R.M. Pranoedjoe Poespaningrat. 2005. "Nonton Wayang dari Berbagai Pakeliran". Yogyakarta: PT. BP. Kedaulatan Rakyat Yogyakarta. 